\title{
A molecular investigation of Saccharina sessilis from the Aleutian Islands reveals a species complex, necessitating the new combination Saccharina subsessilis
}

\author{
Samuel Starko ${ }^{1, *}$, Ga Hun Boo ${ }^{2}$, Patrick T. Martone ${ }^{1}$ and Sandra C. Lindstrom ${ }^{1}$ \\ ${ }^{1}$ Department of Botany \& Biodiversity Research Centre, The University of British Columbia, Vancouver, British Columbia \\ V6T 1Z4, Canada \\ ${ }^{2}$ University Herbarium, University of California, 1001 Valley Life Sciences Building \#2465, Berkeley, CA 94720, USA
}

Cryptic species complexes are increasingly recognized in phycological research, obscuring taxonomy and raising questions about factors influencing speciation. A recent exploration of kelp genetic diversity on Haida Gwaii, British Columbia revealed the existence of a new species, Saccharina druehlii, which is cryptic with Saccharina sessilis. This suggests that molecular investigations further north may be required to elucidate the taxonomy and evolutionary history of this lineage. Although, for several decades, S. sessilis was considered a single highly variable species, its taxonomy has been far from straightforward. In particular, Hedophyllum subsessile (Areschoug) Setchell is now recognized as a synonym of S. sessilis in North America, but as a growth form of Saccharina bongardiana in Far East Russia. To resolve this taxonomic confusion, we sequenced mitochondrial (CO1-5P) and nuclear (internal transcribed spacer) markers of $S$. sessilis populations from the Aleutian Islands, Alaska, USA. Interestingly, none of our sequences matched S. sessilis sensu stricto. Instead, CO1-5P sequences from populations in the central and eastern Aleutians matched exactly S. druehlii with increasing sequence divergence occurring westward. Samples from Attu, the western-most island, composed a genetic group that clearly represents Kjellman's concept of Hafgygia bongardiana f. subsessilis and is distinct enough from S. druehlii and S. sessilis to potentially constitute a distinct species. Therefore, Saccharina subsessilis comb. nov. is proposed for this entity. Our results suggest the existence of a species complex at the crown node of S. sessilis and thus further investigation of Saccharina in Alaskan waters should be conducted to reconstruct the evolutionary history of this fascinating lineage.

Key Words: Aleutian Islands; CO1-5P; DNA barcoding; kelp; phylogenetics; Saccharina; species complex; systematics

\section{INTRODUCTION}

Saccharina is a speciose kelp genus that is widespread throughout temperate regions of the northern hemisphere (Bolton 2010). Species of Saccharina play important foundational roles in nearshore ecosystems and have economic significance through both wild har- vest and large-scale aquaculture operations (Bartsch et al. 2008). Like several other kelp genera, the taxonomic history of Saccharina is convoluted (Bartsch et al. 2008); convergent evolution and morphological plasticity have led to complications in using morphology to distinguish
(9) \$ This is an Open Access article distributed under the terms of the Creative Commons Attribution Non-Commercial License (http://creativecommons.org/licenses/by-nc/3.0/) which permits unrestricted non-commercial use, distribution, and reproduction in any medium, provided the original work is properly cited.
Received January 20, 2018, Accepted April 2, 2018

* Corresponding Author

E-mail: samuel.starko@gmail.com

Tel: +1-604-822-2133, Fax: +1-604-822-6089 
species (Bartsch et al. 2008, McDevit and Saunders 2010). More recently, molecular tools have uncovered cryptic species in some kelp genera, introducing another layer of complexity to the taxonomic challenges posed by kelps (e.g., McDevit and Saunders 2010, Tellier et al. 2011a, Saunders and McDevit 2014). For example, a cryptic sister species of Lessonia nigrescens with a different but overlapping geographical distribution was recently discovered (Tellier et al. 2011a)-a finding which may influence the way that these sympatric populations are managed (Tellier et al. 2011b). Furthermore, strong subspecies molecular structure has been reported in several genera (e.g., Miller et al. 2000: Pelagophycus porra, Lane et al. 2007: Alaria marginata, McDevit and Saunders 2010, Nielsen et al. 2016: Saccharina latissima). In some cases, wide divergences in molecular sequences suggest that additional species or subspecies should be described to reflect the genetic structure of morphospecies (e.g., Boo et al. 2011, Saunders and McDevit 2014, Augyte et al. 2018).

The common ancestor of modern Saccharina species likely originated in the north Pacific and spread to the Atlantic Ocean through the Arctic Ocean with high species diversity currently present on both sides of the Pacific (Bolton 2010). Recently, Saunders and McDevit (2014) conducted a survey of kelps on Haida Gwaii, British Columbia, and uncovered a cryptic sibling of Saccharina sessilis with enough sequence divergence to warrant recognition as a distinct species. Populations containing both sequences were found together on Haida Gwaii. Thus, Saunders and McDevit (2014) used this sequence divergence as evidence of speciation and described $S$. druehlii. The existence of this cryptic species in a northern glacial refugium suggests that further sequencing of northern populations may shed light on the diversification of this clade or uncover additional cryptic species.

Saccharina sessilis (formerly Hedophyllum sessile) and S. druehlii from Haida Gwaii are unique among species of Saccharina in that they lack a stipe at maturity, and haptera emerge directly from the blade (Widdowson 1965, Saunders and McDevit 2014). Although a small stipe is present in young individuals, it is lost through development as the blade grows to fuse with its holdfast (Widdowson 1965). The timing of this transition from stiped to stipeless has caused substantial taxonomic confusion. In particular, one entity, originally described as Hafgygia bongardiana f. subsessilis by Areschoug (1883), then as Laminaria bongardiana f. subsessilis by Kjellman (1889), and finally raised to species status by Setchell (1901) as Hedophyllum subsessile, can have a broad cuneiform base that looks much like a stipe, raising the blade above the substratum. The variation in forms of this entity, however, has led to differing taxonomic interpretations by Western and Russian literature. In Western literature, Hedophyllum subsessile is recognized as a synonym for an early life-stage of S. sessilis (Widdowson 1965). While in the Russian literature, Saccharina bongardiana f. subsessilis is recognized as a distinct form of S. bongardiana (Selivanova et al. 2007, Klochkova et al. 2009). In this study, we sought to clarify the taxonomic placement of Hedophyllum subsessile (Areschoug) Setchell.

\section{MATERIALS AND METHODS}

Hedophyllum subsessile (Areschoug) Setchell was originally distinguished by means of two morphological characteristics (Saunders 1901, Setchell 1901): 1) a cordate to even reniform, stipe-like blade base and 2) necrosis of the central portion of the blade, leaving two separated partial blades, each borne at the extremity of a thickened basal margin that resembles a running rootstock (as described by Areschoug 1883). We collected S. sessilis specimens from the Aleutian Islands, many of which matched this description. Sampling occurred along a longitudinal gradient: Attu Island $(\mathrm{n}=3)$, Hawadax Island (formerly Rat Island) $(\mathrm{n}=1)$, Little Tanaga Island $(\mathrm{n}=1)$, and Akutan Island $(\mathrm{n}=1)$ (Fig. 1).

We sequenced the mitochondrial (CO1-5P) DNA barcoding locus of all specimens and used two methods to distinguish species: phylogenetic distance and Generalized Mixed Yule Coalescent (GMYC) automated species delimitation. The nuclear marker internal transcribed spacer (ITS) was also sequenced for one individual from Attu Island and compared to previously published data.

Genomic DNA was extracted from $\sim 5$ mg of dried thallus ground in liquid nitrogen using a NucleoSpin Plant II kit (Macherey-Nagel, Düren, Germany), following the manufacturer's instructions. The extracted DNA was stored at $-20^{\circ} \mathrm{C}$ and used to amplify CO1-5P.

Primer pairs for amplification and sequencing of CO15P gene were as follows: C1F101 (5'-CCA CHA AYC AYA AAG ATA TWG G-3')-C1R942 (5'-CCH CAN GTA AAC ATR TGR TGA GCC-3'), which were designed for this study and GazF2-GazR2 (Lane et al. 2007). The polymerase chain reaction (PCR) amplification was carried out according to the protocol of Lee et al. (2009), and products were checked by gel electrophoresis in $0.8 \%$ agarose. PCR products were purified using Exo-SAP PCR Clean-Up Mix (MGMED, Seoul, Korea) according to the manufacturer's 


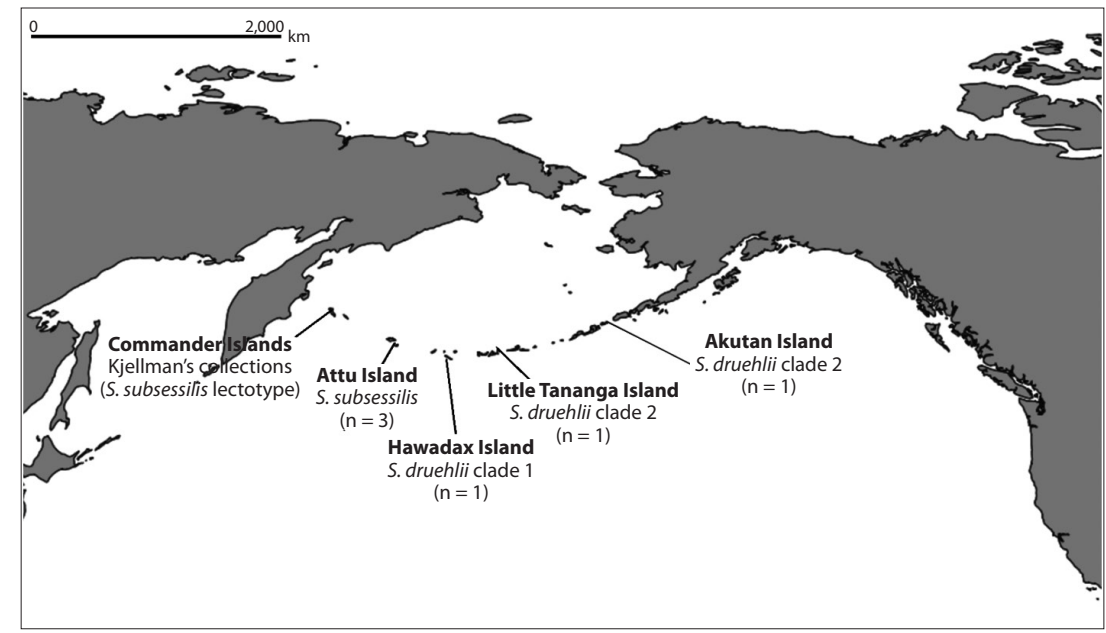

Fig. 1. Map of the Aleutian Islands indicating sampling sites for this study as well as the location of Kjellman's original collection, including the lectotype specimen A-823620 in Uppsala.

instructions and then sent for commercial sequencing (Genotech, Daejeon, Korea). Sequences of the forward and reverse strands were determined for all taxa, and the electropherograms were edited using the program Chromas v.1.45 (McCarthy 1998) and checked manually.

One specimen from Attu Island (indicated with an asterisk in Table 1) was sequenced using high-throughput technology. Genomic DNA was extracted using a CTAB protocol (Rai et al. 2003). A DNA shotgun library was constructed using the Bioo NextFLEX rapid library preparation kit (Bioo Scientific Corporation, Austin, TX, USA) and sequenced using HiSeq 2500 at Genome Quebec
(McGill University, Montreal, Quebec, Canada). CO1-5P and ITS sequences were assembled to a reference sequence of Saccharina nigripes (GenBank No. FJ409198 and AY857894, respectively) using CLC Genomics Workbench 7.1.

In order to include the entire known range of haplotypes for S. sessilis and closely related species (S. druehlii, S. nigripes, S. bongardiana, S. latissima, and Saccharina ochotensis), all available CO1-5P and ITS reference sequences of these species were downloaded from BOLD $(\mathrm{n}=190)$. Additional specimens of Saccharina spp. $(\mathrm{n}=8)$ were sampled from Alaska and British Columbia, and

Table 1. Collection information and GenBank numbers for new CO1-5P sequences generated in this study

\begin{tabular}{|c|c|c|c|c|}
\hline Species & Collection ID & UBC accession No. & Location & GenBank No \\
\hline Saccharina dentigera & ALEUT06_018 & A93601 & Tigalda Island, AK & MH327957 \\
\hline S. dentigera & SCL13510 & A87446 & Attu Island, AK & МH327949 \\
\hline S. dentigera & ALEUT06_389 & No voucher ${ }^{a}$ & Umnak Island, AK & MH327956 \\
\hline S. druehlii & SCL11522 & A86968 & Akutan Harbor, AK & МH327951 \\
\hline S. druehlii & SCL13659 & A93118 & Hawadax Island, AK & MH327954 \\
\hline S. druehlii & ALEUT07_325 & A93121 & Little Tanaga Island, AK & МH327961 \\
\hline S. latissima & SCL_BoulderPatch & No voucher ${ }^{\mathrm{b}}$ & Beaufort Sea, AK & MH327958 \\
\hline S. nigripes & SCL10295 & A85185 & Katmai Bay, AK & МH327953 \\
\hline S. nigripes & SCL11488 & A86955 & Akutan Harbor, AK & MH327952 \\
\hline S. nigripes & SCL12474 & A93602 & Cape Sitkinak, AK & MH327950 \\
\hline S. sessilis & SCL_SeppingsIs & No voucher ${ }^{c}$ & Vancouver Island, BC & MH327959 \\
\hline S. subsessilis & SCL13477 & A93120 & Attu Island, $\mathrm{AK}$ & МН327960 \\
\hline S. subsessilis & ALEUT07_007 & A93600 & Attu Island, AK & МH327955 \\
\hline S. subsessilis* & SCL_AttuIs & A93599 & Attu Island, AK & MH327848 \\
\hline
\end{tabular}

*Also sequenced for ITS (GenBank No. MH257570).

${ }^{a}$ Collected Jul 18, 2006 by Mandy Lindeberg.

${ }^{b}$ Collected Aug 8, 2003 by Brenda Konar, Katrin Iken, and Casey Debenham.

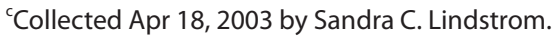




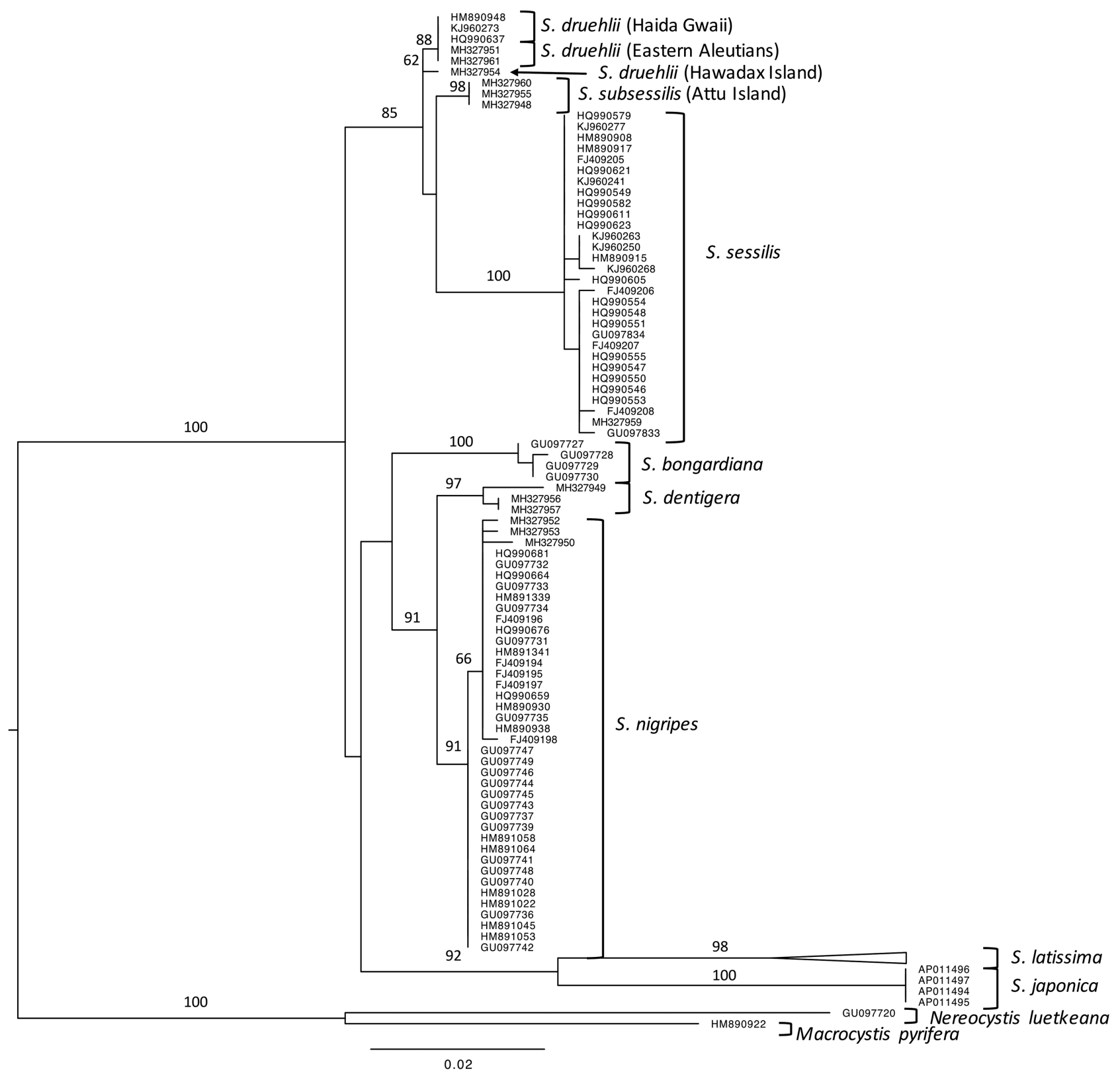

Fig. 2. Maximum likelihood trees for CO1-5P of Saccharina spp., made using RAxML. Node labels indicate bootstrap support, and only support values $>50$ are shown.

CO1-5P was sequenced (Table 1, Supplementary Table S1). Alignments were generated using Multiple Alignment using Fast Fourier Transform (MAFFT) (Katoh et al. 2002), and phylogenetic analyses were performed in RAxML (Stamatakis 2014). GMYC analysis was performed by constructing ultrametric trees in BEAST (Bouckaert et al. 2014) and using the "splits" package in R (v. 3.1.2; Foundation for Statistical Computing, Vienna, Austria) (Fujisawa et al. 2013).

\section{RESULTS AND DISCUSSION}

Three specimens, including two with distinctive wedge-shaped bases, were found to match, with minimal sequence divergence (0.0-0.3\%), Saunders and McDevit's collections of $S$. druehlii from Haida Gwaii. Other specimens from Attu Island $(n=3)$, our farthest west sampling (Fig. 1), were identical in sequence and found to form a distinct clade with both CO1-5P and ITS. Although Attu 


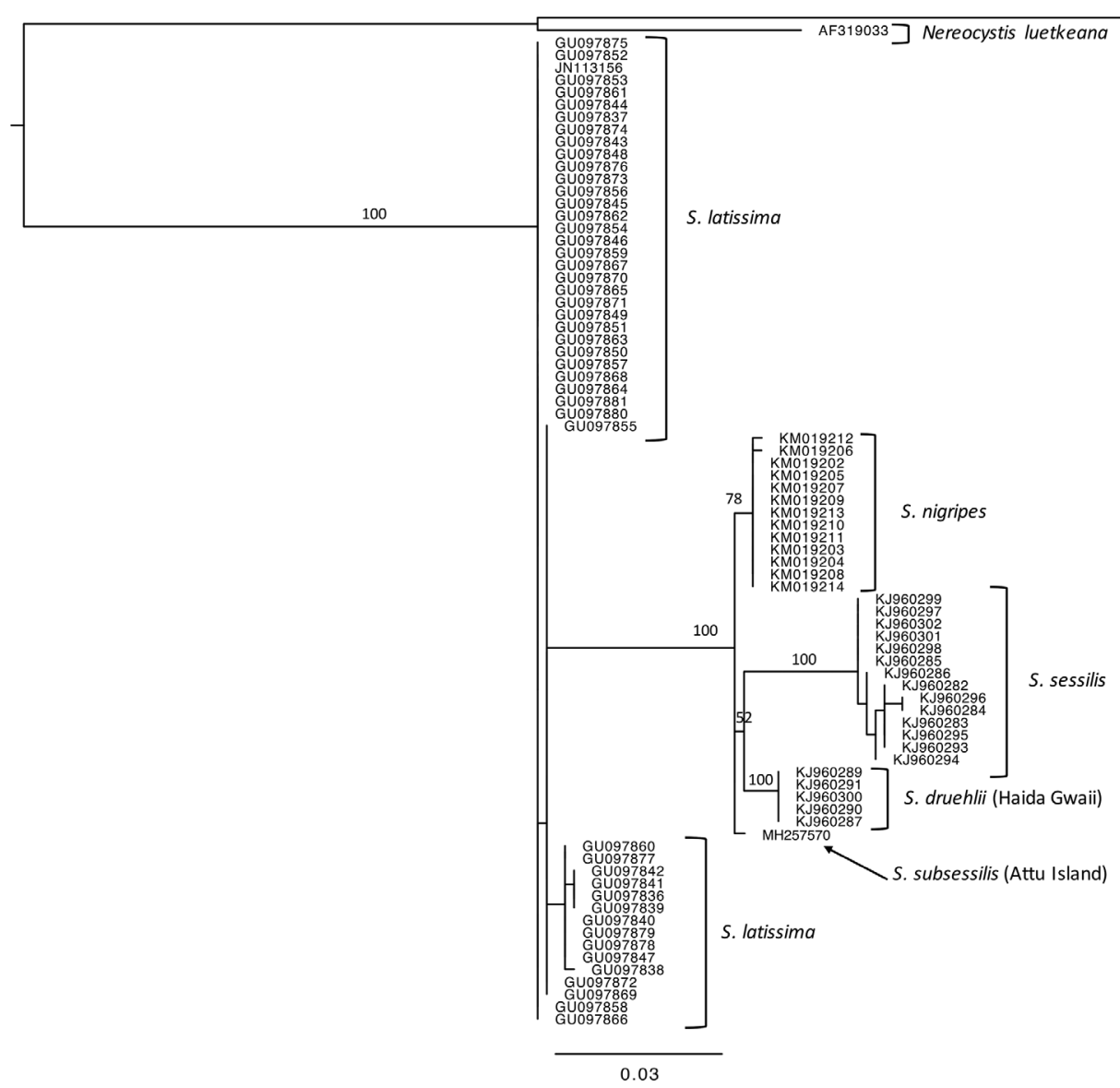

Fig. 3. Maximum likelihood trees for internal transcribed spacer of Saccharina spp., made using RAxML. Node labels indicate bootstrap support, and only support values $>50$ are shown.

sequences were only $\sim 0.8 \%$ divergent in CO1-5P from samples collected from other islands, monophyly was unsupported for both markers (Figs 2 \& 3). Instead, the best tree from maximum likelihood analysis of the CO1$5 \mathrm{P}$ alignment suggests that $S$. druehlii and Attu sequences are paraphyletic, only forming a clade with the inclusion of $S$. sessilis. Furthermore, the genetic distance in
CO1-5P was greater than the intraspecific variation of all currently described species except S. latissima (Table 2), which is likely to require further taxonomic revision due to its unusual genetic variation (McDevit and Saunders 2010). The best tree produced from ITS data also supports paraphyly of $S$. druehlii and Attu specimens, and the Attu specimens were more similar in sequence to $S$.

Table 2. Genetic distance (CO1-5P) between species of Saccharina

\begin{tabular}{lcccc}
\multicolumn{1}{c}{ Species } & Sample size $^{\mathrm{a}}$ & Nearest neighbour (NN) & Distance to NN $^{\mathbf{b}}$ & Max-intra difference $^{\mathbf{b}}$ \\
\hline Saccharina subsessilis & 3 & S. druehlii & 0.79 & 0 \\
S. druehlii & 6 & S. subsessilis & 0.79 & 0.30 \\
S. sessilis & 29 & S. subsessilis & 1.64 & 0.62 \\
S. nigripes & 39 & S. dentigera & 0.91 & 0.30 \\
S. bongardiana & 4 & S. nigripes & 2.13 & 0.30 \\
S. dentigera & 3 & S. nigripes & 0.91 & 0.66 \\
S. latissima Global $^{\mathrm{c}}$ & 104 & S. ochotensis & 4.24 & 1.06 \\
S. latissima NA $^{\mathrm{c}}$ & 20 & S. ochotensis & 4.33 & 0.46 \\
\hline
\end{tabular}

${ }^{a}$ All sequences from BOLD and this study.

${ }^{b}$ Expressed as percent sequence divergence.

c"Global" includes samples from around the world, while "NA" includes only samples from North America. 
nigripes $(0.8 \%)$ than to S. druehlii (1.12\%) (Supplementary Table S2). Although these conflicting genetic signals are likely a consequence of poor resolving power with the ITS locus, they could also be attributed to incomplete lineage sorting (e.g., Maddison and Knowles 2006, Pollard et al. 2006), possibly indicating rapid speciation, or may even suggest hybrid speciation (e.g., Joly et al. 2009). We also identified three specimens that were similar, but genetically distinct from S. nigripes. These specimens were presumed to be members of Saccharina dentigera, which was described from the nearby Commander Islands but has never been sequenced for $\mathrm{CO} 1$.

GMYC analyses using CO1-5P suggested the lumping of the populations from Attu and S. druehlii into a single species (Supplementary Fig. S1). However, the lack of a definitive species concept for the kelps (Bolton 2010) makes the decision on how to taxonomically treat these entities especially difficult, particularly given that both ITS and CO1-5P indicated divergence between populations and similar divergence to $S$. dentigera and S. nigripes (Table 2 ), which are currently recognized as distinct. The magnitude of divergence between and within clades suggests that these populations may be part of a species complex (Saunders 2005, Lane et al. 2007), requiring further sampling and sequencing to elucidate species groupings. As we now discuss, lumping these entities into a single species would require a taxonomic demotion of $S$. druehlii (making it a junior synonym of S. subsessilis); thus, we choose to be conservative and recognize both as distinct. We acknowledge, however, that given our results, future work may synonymize these species under S. subsessilis, if monophyly is supported with comprehensive sampling of more genes and / or populations.

Our results demonstrate that three distinct entities make up what, prior to Saunders and McDevit (2014), had been called S. sessilis. While S. sessilis sensu stricto likely has a wide distribution, $S$. druehlii is a northern species that reaches its southern limit on Haida Gwaii (Supplementary Fig. S2). Additionally, a third clade is present on Attu, in the western Aleutians. This suggests that a geographical cline may separate $S$. druehlii from this third, western clade. This biogeographical pattern is further supported by the sequence from Hawadax Island, the furthest west sample matching $S$. druehlii, that showed divergence from all other populations $(0.2 \%$ from other $S$. druehlii samples) (Fig. 2). However, the Hawadax Island sequence was distinct from other S. druehlii in base-pair differences that were not shared with S. subsessilis. Together, our molecular data suggest that Setchell (1901) was correct in recognizing Hedophyllum subsessile as distinct from H. sessile. Thus, placements of H. subsessile into $S$. bongardiana f. subsessilis by Russian literature and into S. sessilis by Western literature, were both incorrect. Instead, it is necessary to resurrect the species epithet subsessile and make the combination Saccharina subsessilis for this entity:

\section{Saccharina subsessilis (Areschoug) Starko \& S. C. Lind- strom}

Basionym. Hafgygia bongardiana f. subsessilis Areschoug 1883, p. 5.

Homotypic synonyms. Laminaria bongardiana f. subsessilis Kjellman 1889, p. 43; Hedophyllum subsessile (Areschoug) Setchell 1901, p. 122.

Possible heterotypic synonym. Streptophyllum spirale (Yendo) Miyabe \& Nagai in Nagai 1941, p. 96 [basionym: Hedophyllum spirale Yendo 1903, p. 165, pl. VI, figs 1-7 (excl. f. kamtshatkensis)]. Type locality: Shimushu Island, Northern Kurile Island, Russia.

Saccharina subsessilis (Areschoug) Starko \& S. C. Lindstrom was originally described by Areschoug (1883, p. 5) from material collected by Kjellman on Bering Island between Aug 14 and 19, 1879. Areschoug included two other forms of Hafgygia bongardiana: f. normalis and f. furcata. Forma subsessilis was distinguished by the blades developing directly out of the top of the conglobated haptera. Although Areschoug mentioned specimens from both Bering Island and Sitka, this clearly refers to $H$. bongardiana sensu lato. Since Areschoug names Ruprecht specifically in addition to Kjellman, it is likely that the Sitka specimens represent material examined by Ruprecht (Kjellman did not visit Sitka; Ruprecht worked up material collected there by Mertens, Kastalsky, and Wosnessensky and illustrated by Postels) (Lindstrom 2009). We hereby designate A-823620 in Uppsala (UPS) as the lectotype of $H$. bongardiana f. subsessilis (Fig. 4). This specimen is one of two of this form collected by Kjellman on Bering Island between Aug 14 and 19, 1879 and deposited in the Uppsala herbarium. We consider the other specimen in UPS (A823624) to be a syntype.

Kjellman (1889, p. 43) recognized the form as Laminaria bongardiana f. subsessilis (Areschoug) Kjellman in his treatise on the marine algae of the Bering Sea collected on the Vega expedition. Kjellman noted that f. subsessilis was the smallest of the forms of L. bongardiana and showed affinity with L. sessilis Agardh in that the stipe was almost indiscernible, if not lacking: the haptera emerging from the thick cuneiform base of the blade directly.

Setchell (1901, p. 122) raised the form to specific rank when he made the new combination, Hedophyllum sub- 

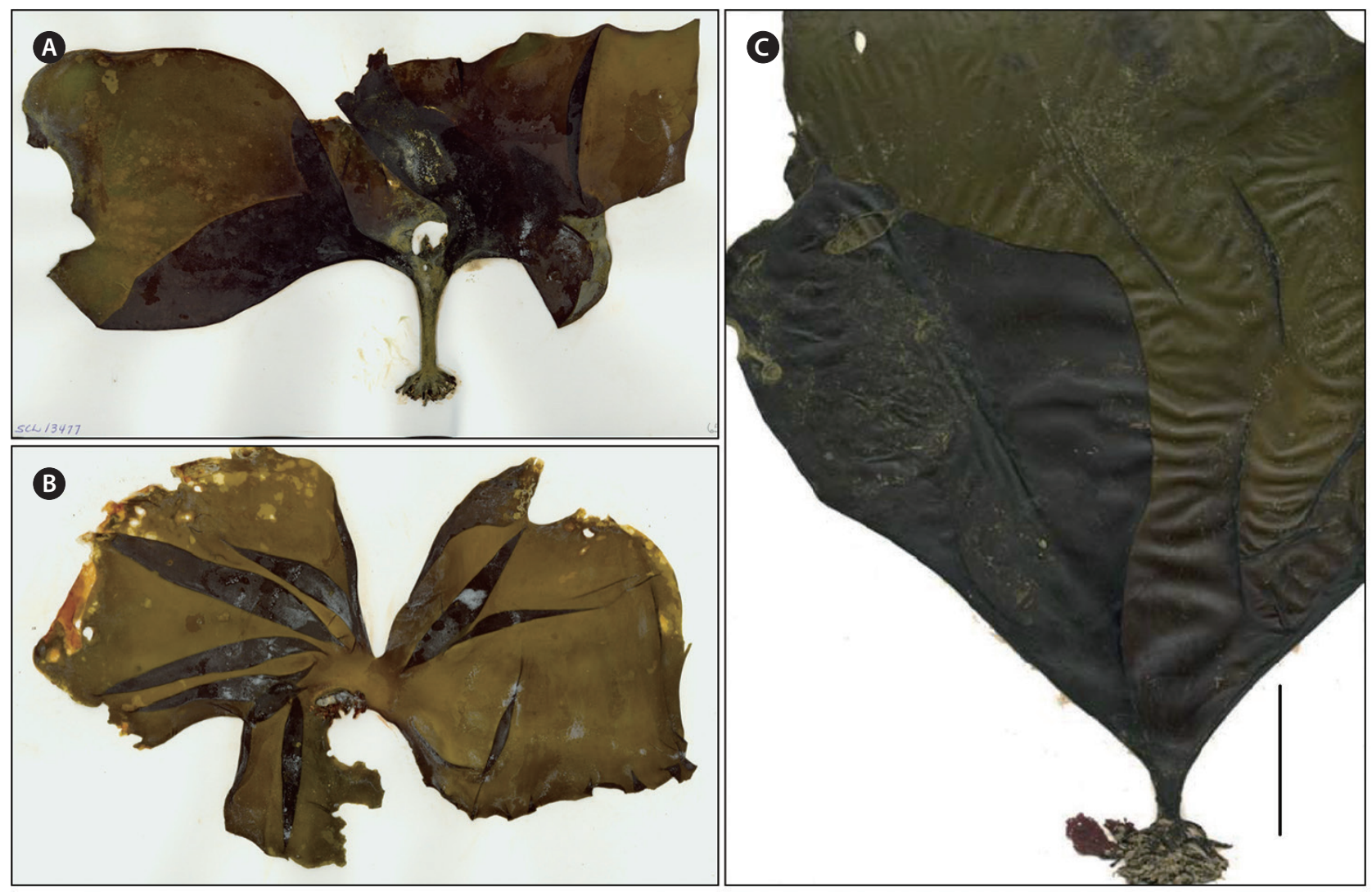

Fig. 4. Representative specimens of Saccharina subsessilis UBC A93120, Chichagof Harbor, Attu Island (A), Saccharina druehlii clade 1 UBC A93118, Hawadax Island (B), and Saccharina druehlii clade 2 UBC A93121, Little Tanaga Island (C). Scale bar represents: C, $5 \mathrm{~cm}$.
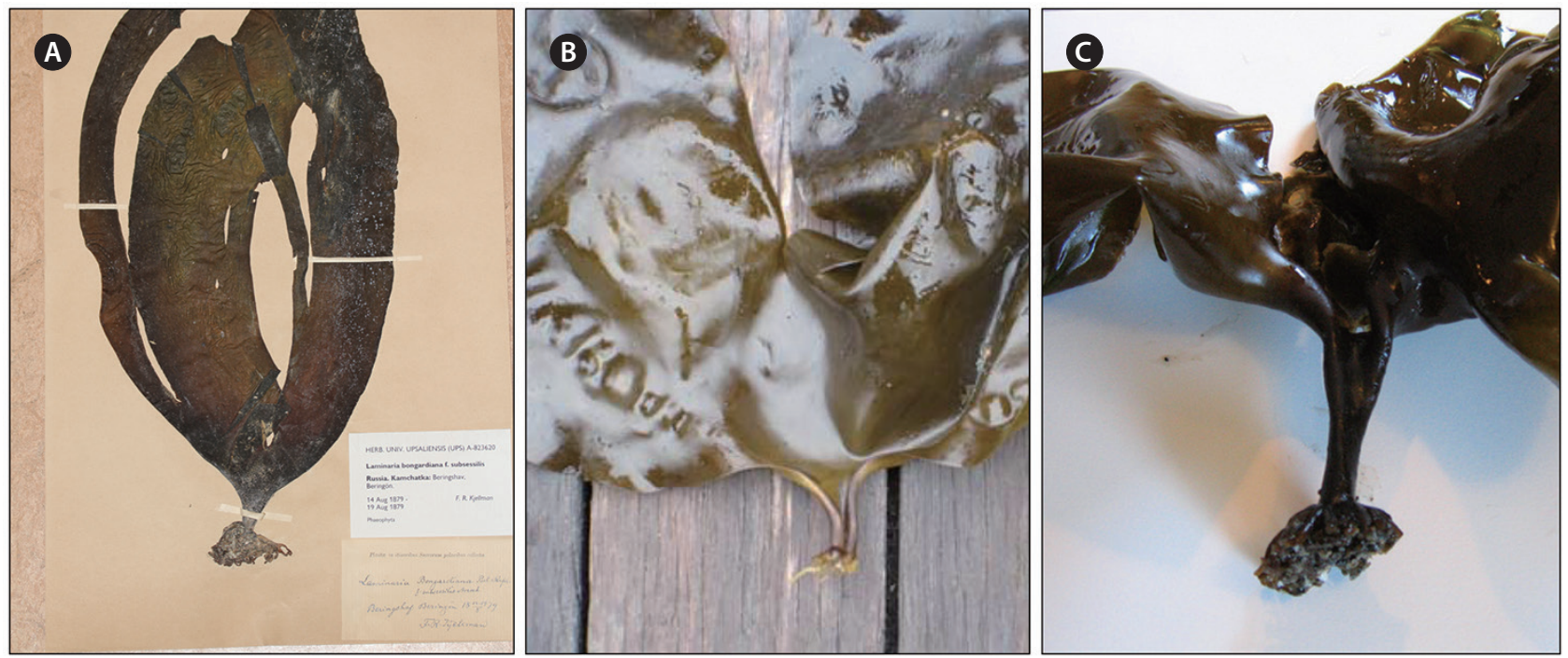

Fig. 5. The lectotype of Saccharina subsessilis (Uppsala A-823620) in the Uppsala Herbarium (A) and specimens from Attu Island (B \& C). Note the stipe-like base where the blade meets the holdfast, the thickened margin, and the splitting of the blade down the middle. 
sessile (Areschoug) Setchell. He provided a more thorough description of what he thought was the same species, based on collections from Amaknak Island, Unalaska Bay (this was likely what we recognize here as $S$. druehlii). Widdowson (1965, p. 1410) reduced H. subsessile to a synonym of $H$. sessile. Widdowson had looked for the type of Hafgygia bongardiana f. subsessilis in Stockholm (S). Although Areschoug retired to Stockholm, he held faculty status at UPS prior to his retirement, and Kjellman, on whose specimens Areschoug based his new form, was also on the faculty at UPS (Wynne 2006) so it is unclear why Widdowson looked for the specimens of the species in Stockholm rather than UPS. Widdowson did mention the specimens in UPS, citing a personal communication from R. F. Scagel. He stated, "Although it seems likely that these specimens were the basis of Areschoug's descriptions, there is no concrete evidence of this." This is hardly surprising in that the detailed protocols associated with typification were not developed until the twentieth century. Claiming "Areschoug's material could not be found," Widdowson then selected as neotype the material in UC that Setchell had examined in raising Hafgygia bongardiana f. subsessilis to specific rank. As noted above, given the geographical patterns observed in our study, Widdowson's neotype is likely to be S. druehlii rather than $S$. subsessilis. However, according to the International Code of Nomenclature for Algae, Fungi, and Plants (Melbourne Code) (2012) "9.7. [a] neotype (McNeill et al. 2012) is a specimen or illustration selected to serve as nomenclatural type if no original material is extant, or as long as it is missing." Since the original material on which the name $S$. subsessilis is based exists, Widdowson's neotype can be disregarded in relation to the nomenclature of either S. subsessilis or S. druehlii. Thus, S. druehlii remains a valid name for the entity present in the eastern Aleutians and on Haida Gwaii, and we recognize S. subsessilis as a species from the western Aleutians and Commander Islands that may or may not extend further west into Russia (Selivanova et al. 2007, Klochkova et al. 2009) (Supplementary Fig. S2).

The distinctness of westernmost Aleutian Island material from more easterly collections is perhaps hardly surprising. The 1,600 km island arc is composed of clusters of island groups separated by increasingly wider and deeper passages from east to west (Stabeno et al. 2005). Lindstrom et al. (2015) observed western Aleutian Pyropia taeniata occurred in the mid to high intertidal in contrast to the low intertidal habitat of more easterly populations, but only three species of foliose Bangiales from there had a single unique nucleotide in their $r b c \mathrm{~L}$ sequences. However, other species of red algae appear to show more uniqueness in the western Aleutian Islands (Lindstrom unpublished data).

Although our sampling was limited to only a few sites, there are possible morphological differences between $S$. subsessilis and S. druehlii. In general, the stipe-like base is much more pronounced and robust in S. subsessilis than in S. druehlii. In these specimens, the base of the blade narrows and becomes canaliculate like a stipe, and older individuals form splits in their blades as they widen in a semicircular fashion. Setchell (1901) suggested that the samples that he inspected (which are likely to be $S$. druehlii) could be indistinguishable from S. sessilis after their second year of development. Indeed, the collections by Saunders and McDevit (2014) are not conspicuously distinct from collections of $S$. sessilis, and in our samples, the stipe-like base of $S$. druehlii was either less evident or fully absent in larger individuals. However, the base of the blade was much wider in these larger samples than would be typical of S. sessilis, and blades tended to split in a similar manner to S. subsessilis. The striking morphology of samples from Attu (Figs $4 \& 5$ ) suggest that S. subsessilis is much more distinguishable from S. sessilis than S. druehlii, however, and differences between these species may become even more apparent as individuals age and grow. Saunders and McDevit (2014) also suggested that $S$. druehlii was strongly bullate in morphology as an adult. Because none of our collections corroborate this description, it appears that bullation is a population level morphological feature rather than one at the level of species. Instead, reassessment of their images of S. druehlii on the Barcode of Life Database (BOLD) suggest that the base of their samples, like ours, may be morphologically distinct from the rest of the blade (BOLD accession No.: MACRO3473-12, MACRO3474-12). Future work should assess the morphology of the blades (especially basal regions) prior to sequencing specimens believed to be $S$. sessilis, S. druehlii, or S. subsessilis. In doing so, we may be able to determine a way to distinguish these entities in the field in locations in which they overlap.

\section{CONCLUSION}

Regardless of how this species complex came to be, it is clear from this study and others (e.g., Nielsen et al. 2016) that Saccharina serves as an interesting case study into the dynamics of speciation in kelps. Considering our inability to pose a definitive species concept for this group, we would stand to gain much from intensively 
studying the structure of key genera on both global and local scales. Future work should continue to investigate the phylogenetic structure of populations of Saccharina to reconstruct the evolutionary history of the lineage and incorporate morphological, biogeographical and ecological characters to better understand the factors differentiating genetic species. In doing so, we may not only determine how best to taxonomically treat the species complex presented in this study but also learn more about drivers of speciation in brown algae in general.

\section{ACKNOWLEDGEMENTS}

We thank Mandy Lindeberg for sharing specimens collected in the Aleutian Islands and Jochen Halfar and Paul Tate for facilitating Sandra Lindstrom's collections of specimens in the Aleutian Islands. We also acknowledge the Phycological Society of America for support through a Grant-in-Aid of Research to SS. One specimen from Attu was sequenced using NGS as part of an ongoing collaboration with S. Graham, M. Soto Gomez, and P. Keeling. We thank them for facilitating the acquisition of these sequences.

\section{SUPPLEMENTARY MATERIAL}

Supplementary Table S1. List of published sequences used in this study (http://e-algae.org).

Supplementary Table S2. Genetic distance (ITS) between species of Saccharina (http://e-algae.org).

Supplementary Fig. S1. Generalized Mixed Yule Coalescent analysis using CO1-5P gene tree. Ultrametric tree was constructed in BEAST using a HKY model of evolution and strict clock priors. Prior choice (relaxed clock, random local clock) did not influence the resulting topology or species clustering (http://e-algae.org).

Supplementary Fig. S2. A map showing the known and putative distributions of Saccharina sessliis, S. subsessilis, and S. druehlii (http://e-algae.org).

\section{REFERENCES}

Areschoug, J. E. 1883. Obscrvationes phycologicae. IV. Nova Acta Regiae Soc. Sci. Upsaliensis Ser. III 12:5.

Augyte, S., Lewis, L., Lin, S., Neefus, C. D. \& Yarish, C. 2018. Speciation in the exposed intertidal zone: the case of Saccharina angustissima comb. nov. \& stat. nov. (Lami- nariales, Phaeophyceae). Phycologia 57:100-112.

Bartsch, I., Wiencke, C., Bischof, K., Buckholz, C. M., Buck, B. H., Eggert, A., Feuerpfeil, P., Hanelt, D., Jacobsen, S., Karez, R., Karsten, U., Molis, M., Roleda, M. Y., Schubert, H., Schumann, R., Valentin, K., Weinberger, R. \& Wiese, J. 2008. The genus Laminaria sensu lato: recent insights and developments. Eur. J. Phycol. 43:1-86.

Bolton, J. J. 2010. The biogeography of kelps (Laminariales, Phaeophyceae): a global analysis with new insights from recent advances in molecular phylogenetics. Helgol. Mar. Res. 64:263-279.

Boo, G. H., Lindstrom, S. C., Klochkova, N. G., Yotsukura, N., Yang, E. C., Kim, H. G., Waaland, J. R., Cho, G. Y., Miller, K. A. \& Boo, S. M. 2011. Taxonomy and biogeography of Agarum and Thalassiophyllum (Laminariales, Phaeophyceae) based on sequences of nuclear, mitochondrial, and plastid markers. Taxon 60:831-840.

Bouckaert, R., Heled, J., Kühnert, D., Vaughan, T., Wu, C. -H., Xie, D., Suchard, M. A., Rambaut, A. \& Drummond, A. J. 2014. BEAST 2: a software platform for Bayesian evolutionary analysis. PLoS Comput. Biol. 10:e1003537.

Fujisawa, T. \& Barraclough, T. G. 2013. Delimiting species using single-locus data and the Generalized Mixed Yule Coalescent approach: a revised method and evaluation on simulated data sets. Syst. Biol. 62:707-724.

Joly, S., McLenachan, P. A. \& Lockhart, P. J. 2009. A statistical approach for distinguishing hybridization and incomplete lineage sorting. Am. Nat. 174:E54-E70.

Katoh, K., Misawa, K., Kuma, K. \& Miyata, T. 2002. MAFFT: a novel method for rapid multiple sequence alignment based on fast Fourier transform. Nucleic Acids Res. 30:3059-3066.

Kjellman, F. R. 1889. Om Beringhafvets Algflora. Kgl. Svenska Vetenskapsakad Handl. 23:1-55.

Klochkova, N. G., Korolyova, T. N. \& Kusidi, A. E. 2009. Marine algae of Kamchatka and surrounding areas. Vol. 1. KamchatNIRO Press, Petropavlovsk-Kamchatskii, 218 pp. (in Russian).

Lane, C. E., Lindstrom, S. C. \& Saunders, G. W. 2007. A molecular assessment of northeast Pacific Alaria species (Laminariales, Phaeophyceae) with reference to the utility of DNA barcoding. Mol. Phylogenet. Evol. 44:634648.

Lee, K. M., Boo, G. H., Riosmena-Rodriguez, R., Shin, J. -A. \& Boo, S. M. 2009. Classification of the genus Ishige (Ishigeales, Phaeophyceae) in the North Pacific Ocean with recognition of Ishige foliacea based on plastid $r b c \mathrm{~L}$ and mitochondrial cox3 gene sequences. J. Phycol. 45:906913.

Lindstrom, S. C. 2009. The biogeography of seaweeds in 
Southeast Alaska. J. Biogeogr. 36:401-409.

Lindstrom, S. C., Lindeberg, M. R. \& Guthrie, D. A. 2015. Marine macroalgae of the Aleutian Islands: I. Bangiales. Algae 30:247-263.

Maddison, W. P. \& Knowles, L. L. 2006. Inferring phylogeny despite incomplete lineage sorting. Syst. Biol. 55:21-30.

McCarthy, C. 1998. Chromas, version 1.45. School of Health Science, Griffith University, Southport, Queensland, Australia.

McDevit, D. C. \& Saunders, G. W. 2010. A DNA barcode examination of the Laminariaceae (Phaeophyceae) in Canada reveals novel biogeographical and evolutionary insights. Phycologia 49:235-248.

McNeill, J., Barrie, F. R., Buck, W. R., Demoulin, V., Greuter, W., Hawksworth, D. L., Herendeen, P. S., Knapp, S., Marhold, K., Prado, J., Prud'homme van Reine, W. F., Smith, G. F., Wiersema, J. H. \& Turland, N. J. 2012. International Code of Nomenclature for algae, fungi, and plants (Melbourne Code). Regnum Vegetabile 154. Koeltz Scientific Books, Königstein, 208 pp.

Miller, K. A., Olsen, J. L. \& Stam, W. T. 2000. Genetic divergence correlates with morphological and ecological subdivision in the deep-water elk kelp, Pelagophycus porra (Phaeophyceae). J. Phycol. 36:862-870.

Nielsen, M. M., Paulino, C., Neiva, J., Krause-Jensen, D., Bruhn, A. \& Serrão, E. A. 2016. Genetic diversity of Saccharina latissima (Phaeophyceae) along a salinity gradient in the North Sea-Baltic Sea transition zone. J. Phycol. 52:523-531.

Pollard, D. A., Iyer, V. N., Moses, A. M. \& Eisen, M. B. 2006. Widespread discordance of gene trees with species tree in Drosophila: evidence for incomplete lineage sorting. PLoS Genet. 2:e173.

Rai, H. S., O’Brien, H. E., Reeves, P. A., Olmstead, R. G. \& Graham, S. W. 2003. Inference of higher-order relationships in the cycads from a large chloroplast data set. Mol. Phylogenet. Evol. 29:350-359.

Saunders, D. A. 1901. Papers from the Harriman Alaska Expedition. XXV. The algae. Proc. Wash. Acad. Sci. 3:391-486.
Saunders, G. W. 2005. Applying DNA barcoding to red macroalgae: a preliminary appraisal holds promise for future applications. Philos. Trans. R. Soc. B Biol. Sci. 360:1879-1888.

Saunders, G. W. \& McDevit, D. C. 2014. A DNA barcode survey of Haida Gwaii kelp (Laminariales, Phaeophyceae) reveals novel ecological and distributional observations and Saccharina druehlii sp. nov. Botany 92:821-826.

Selivanova, O. N., Zhigadlova, G. G. \& Hansen, G. I. 2007. Revision of the systematics of algae in the order Laminariales (Phaeophyta) from the Far-Eastern seas of Russia on the basis of molecular-phylogenetic data. Russ. J. Mar. Biol. 33:278-289.

Setchell, W. A. 1901. Notes on algae, I. Zoe 5:121-129.

Stabeno, P. J., Kachel, D. G., Kachel, N. B. \& Sullivan, M. E. 2005. Observations from moorings in the Aleutian Passes: temperature, salinity and transport. Fish. Oceanogr. 14(Suppl. 1):39-54.

Stamatakis, A. 2014. RAxML version 8: a tool for phylogenetic analysis and post-analysis of large phylogenies. Bioinformatics 30:1312-1313.

Tellier, F., Tapai, J., Faugero, S., Destombe, C. \& Valero, M. 2011a. The Lessonia nigrescens species complex (Laminariales, Phaeophyceae) shows strict paraptry and complete reproductive isolation in a secondary contact zone. J. Phycol. 47:894-903.

Tellier, F., Vega, J. M. A., Broitman, B. R., Vasquez, J. A., Valero, M. \& Faugeron, S. 2011b. The importance of having two species instead of one in kelp management: the Lessonia nigrescens species complex. Cah. Biol. Mar. 52:455-465.

Widdowson, T. B. 1965. A taxonomic study of the genus $\mathrm{He}$ dophyllum Setchell. Can. J. Bot. 43:1409-1420.

Wynne, M. J. 2006. Portraits of marine algae: an historical perspective. University of Michigan Herbarium, Ann Arbor, MI, $180 \mathrm{pp}$.

Yendo, K. 1903. Hedophyllum spirale sp. nov., and its relation to Thalassiophyllum and Arthrothamnus. Bot. Mag (Tokyo) 17:165-173. 